\title{
Regress i skadeforsikring
}

\author{
Professor Trine-Lise Wilhelmsen, \\ Universitetet i Oslo, Nordisk institutt for sjørett, Juridisk fakultet
}

\section{Innledning}

Temaet for denne artikkelen er regress i skadeforsikring. Skadeforsikring er «forsikring mot skade på eller tap av ting, rettigheter eller andre fordeler, forsikring mot erstatningsansvar eller kostnader, og annen forsikring som ikke er personforsikring». ${ }^{1}$ Regress er et krav om tilbakebetaling fra A for en ytelse som man har betalt til B, men som A (også) er ansvarlig for. Forsikring er finansiering av en skadevoldende begivenhet hvis og når den måtte oppstå. Forsikring gjennomføres ved at kunden - forsikringstaker ${ }^{2}$ - overfører den aktuelle risikoen for skade eller tap til et forsikringsselskap mot en premie. Normalt skjer dette som en enkel transaksjon mellom to parter, slik at selskapet betaler ut erstatning når forsikringstilfellet inntreffer uten noe etterfølgende regressoppgjør. Spørsmålet om et etterfølgende regresskrav mot en annen enn utbetalingen skjedde til kan likevel oppstå i forskjellige sammenhenger:

Den første og mest sentrale problemstillingen er situasjonen hvor en skadevolder A påfører skadelidte B en skade som er dekket under B's forsikring mot tingskade eller formueskade C. I denne situasjonen er utgangspunktet at A er ansvarlig overfor B etter erstatningsrettslige regler, mens C er ansvarlig overfor B etter forsikringskontrakten. B vil normalt kreve sitt tap dekket hos C. Spørsmålet blir da i hvilken utstrekning C har krav på regress mot A. Dersom A har ansvarsforsikring, får man et tilsvarende spørsmål om C's regress mot denne ansvarsforsikringen. Dette er altså et spørsmål om forholdet mellom en forsikring mot tingog formueskade og en ansvarlig skadevolder og hans ansvarsforsikring og diskuteres under punkt 3 nedenfor.

I forlengelsen av denne situasjonen kan man tenke seg at A ikke har voldt skaden alene, men sammen med D. Forholdet mellom skadelidte B's forsikring mot ting og formueskade og A og D samt deres ansvarsforsikringer blir som ovenfor. Men hvis A og/eller D har ansvarsforsikring, får man i tillegg spørsmål om forholdet mellom disse to ansvarsforsikringene eller mellom en ansvarsforsikring og en medansvarlig personlig skadevolder. Denne problemstillingen diskuteres under punkt 4 nedenfor.

$1 \quad$ Lov 16. juni 1989 nr. 69 om forsikringsavtaler (fal) $§ 1-1$.

2 Den som inngår en individuell eller kollektiv forsikringsavtale med selskapet, jf. fal. § 1-2 bokstav b. 
En tredje problemstilling er hvor B har tegnet flere forsikringer som dekker samme $\emptyset$ konomiske interesse. Dersom det ene selskapet dekker skaden, er det spørsmål om dette selskapet har regress mot det andre selskapet. I motsetning til de tilfeller som er omtalt ovenfor er det her ingen skadevolder som er ansvarlig etter alminnelig erstatningsrett, men to forsikringsselskaper som er ansvarlig overfor samme forsikringstaker/sikrede etter hver sin avtale. Dette behandles under punkt 5 .

Et fjerde problem er hvor et forsikringsselskap ved en feil betaler erstatning for et forsikringstilfelle som skulle vært dekket av et annet selskap, og deretter krever regress mot det andre selskapet, se punkt 6.

Den siste problemstillingen gjelder spørsmålet om forsikringsselskapet kan få regress mot egen forsikringstaker. Hvis selskapet har et krav mot forsikringstaker vil dette normalt føre til avkortning i den erstatningen selskapet skal dekke når forsikringstilfellet er inntruffet, og det blir ikke tale om regresskrav. Men en forsikring kan gi rettigheter til en medforsikret tredjemann eller en skadelidt som går lenger enn forsikringstakerens rett etter avtalen. Når selskapet har betalt ut erstatning til tredjemann etter slike regler, er det spørsmål om det kan søke regress fra forsikringstakeren for sine utbetalinger, se punkt 7.

Det kan tenkes at et forsikringsselskap betaler erstatning til sikrede ved en feil, og deretter krever beløpet tilbakebetalt. ${ }^{3}$ Grunnlaget for dette er condictio indebiti, og dette diskuteres ikke i denne artikkelen.

Regress innebærer overflytting av tap og koster tid og penger. ${ }^{4}$ Generelt er det mer $\varnothing$ konomisk om tapet plasseres riktig i første omgang slik at man klarer seg med en overflytting fra debitor til kreditor. Skal en regressadgang forsvares, bør fordelen ved regressen oppveie ulempene ved regress i form av ressursbruk. Det er derfor et generelt spørsmål hvilke hensyn som kan forsvare de ekstrakostnadene som utløses gjennom regressregler, se punkt 8 .

Innledningsvis gis det en oversikt over forsikringsavtalen, aktørene og rettigheter etter avtalen som nødvendig bakgrunn for å diskutere reglene om regress.

\title{
2 Forsikringsavtalen, aktører og rettigheter etter avtalen
}

\author{
Se Rt-1997-1029, på s. 1035-1036 \\ Se Trine-Lise Wilhelmsen, Samspillet mellom forsikring og erstatning ved tingsskader, \\ Jussens Venner 1990 (Wilhelmsen 1990) s. 149 f. på s. 157; Jan Hellner, Skadeståndsrätt, \\ Stockholm 1985 (Hellner 1985) s. 31; Hans Jacob Bull, Tredjemannsdekninger $i$ \\ forsikringsforhold, Oslo, 1988 (Bull 1988) s. 350 og s. 353.
}


Skadeforsikring omfatter som nevnt «forsikring mot skade på eller tap av ting, rettigheter eller andre fordeler, forsikring mot erstatningsansvar eller kostnader, og annen forsikring som ikke er personforsikring». ${ }^{5}$ Forsikring mot skade på eller tap av ting omfatter den forsikrede gjenstandens objektive kapitalverdi når gjenstanden skades eller går tapt. Forsikringen inneholder normalt en liste over de farer forsikringen dekker mot. Dette vil typisk være brann, eksplosjon, rørledningsbrudd, vannskade, tyveri og hærverk, samt ofte en mer uspesifisert tilleggsdekning for «plutselig og uforutsett» skade. ${ }^{6}$ Tapsfeltet er normalt angitt som skade og totaltap. Forsikring mot tap av «rettigheter eller andre fordeler» refererer i hovedsak til avbruddsforsikring eller inntektsforsikring, som dekker de inntekter sikrede taper i forbindelse med skade eller tap av den forsikrede gjenstand, evt. knyttet til andre forhold. ${ }^{7}$ Forsikring «mot erstatningsansvar» er knyttet til erstatningsretten og omfatter sikredes potensielle erstatningsansvar overfor tredjemann. En slik forsikring dekker normalt ansvarsgrunnlagene etter alminnelig erstatningsrett med unntak for kontraktansvar, men kontraktansvar kan også være omfattet. ${ }^{8}$

De fleste forsikringsavtaler som omtales i denne artikkelen lar seg kategorisere innenfor de grupper som her er nevnt. En type forsikring er mer problematisk; nemlig eierskifteforsikring eller boligselgerforsikring, som dekker selgerens ansvar overfor kjøperen etter avhendingsloven. ${ }^{9}$ Denne forsikringen inneholder elementer av ansvarsforsikring ved at den dekker sikredes (selgerens) erstatningsansvar overfor kjøperen, med den inneholder også andre elementer fordi den dekker prisavslag, retting og heving. Den kan derfor også sees som forsikring mot kostnader eller som «annen forsikring som ikke er personforsikring». Kategoriseringen av forsikringen har betydning for hvilke regler som vil gjelde $\mathrm{i}$ en evt. regressomgang. ${ }^{10}$

En sondring som går på tvers av typer forsikring er om den er frivillig eller tvungen. ${ }^{11}$ Utgangspunktet er at det er frivillig å tegne forsikring, men på enkelte områder foreligger det forsikringsplikt. Dette gjelder bl.a. for eier av bil, som har plikt til å tegne forsikring mot skade som bilen gjør, ${ }^{12}$ for arbeidsgiver, som har plikt til å tegne forsikring for skade på sine ansatte, ${ }^{13}$ og for advokater, som har plikt til å stille sikkerhet for det ansvaret de kan pådra seg gjennom sin advokatvirksomhet. ${ }^{14}$ Skadelidtes rettigheter mot forsikringsselskapet vil være

Fal. § 1-1.

Hans Jacob Bull, Forsikringsrett, 2008 (Bull 2008) s. 28

Bull 2008 s. 28-29.

Bull 2008 s. 29.

Lov 3. juli $1992 \mathrm{nr} .93 \mathrm{om}$ avhending av fast eigedom (avhl.).

Trine-Lise Wilhelmsen, Forsikring og regress ved salg av bolig, Tidsskrift for erstatningsrett, forsikringsrett og trygderett, $2018 \mathrm{nr}$. 2/3 (Wilhelmsen 2018) s. 112-114.

Bull 2008 s. 32-33.

Lov 3. februar 1961 om ansvar for skade som motorvogner gjer (bal.) $\$ 15$.

Lov 16 juni $1989 \mathrm{nr} .65$ om yrkesskadeforsikring (yfl.) § 3. Yfl. behandles ikke ytterligere

her fordi den gjelder skade på person hvor andre regler kommer inn.

14 Lov 13. august $1915 \mathrm{nr} .5$ om domstolene (domstolloven) $§ 222$ første ledd, jf.

Advokatforskriften FOR-1996-12-20-1161 kap. 2. 
bestemt av de aktuelle lovreglene, mens rettighetene til forsikringstaker/sikrede bestemmes av forsikringsavtalen.

En forsikringsavtale inngås mellom et forsikringsselskap og en forsikringstaker som parter i avtaleforholdet. Tradisjonelt omtales likevel forsikring som et trepartsforhold hvor forsikringstakeren er den som inngår avtalen med selskapet mens sikrede er den som har krav på erstatning når skade skjer. ${ }^{15} \mathrm{I}$ de fleste situasjoner er forsikringstaker og sikrede samme person. Begrunnelsen for en slik todelt terminologi er først og fremst at forsikringstaker og sikrede har forskjellige plikter under avtalen. Forsikringstaker har som avtalepart plikt til å betale premie, og han har plikt til å gi riktige og fullstendige opplysninger når avtalen inngås. ${ }^{16}$ Sikrede er derimot pålagt en rekke omsorgsplikter under den løpende forsikringsperioden. Disse består i ikke å endre risikoen i strid med avtalens forutsetninger, ${ }^{17}$ overholde sikkerhetsforskrifter, ${ }^{18}$ vise generell aktsomhet i forhold til den risikoen som er dekket ${ }^{19}$ og overholde regler om rednings- og meldeplikt. ${ }^{20}$ Brudd på disse reglene fører ikke uten videre til at selskapet er uten ansvar, men til at selskapet kan avkorte i erstatningen ut fra graden av skyld, årsaksforholdet og andre omstendigheter. Generelt kan man si at sikrede i utgangspunktet er beskyttet mot ordinær uaktsomhet, men må finne seg i avkortning/ingen dekning ved grov uaktsom fremkallelse av forsikringstilfellet, brudd på sikkerhetsforskrifter hvor han er mer enn lite å laste og endring av risiko som han har fremkalt eller kjenner til.

I tillegg til sondringen mellom forsikringstaker og sikrede sondrer man mellom sikrede og medforsikrede. ${ }^{21}$ En medforsikret er normalt en person som har en $\varnothing$ konomisk interesse i den gjenstanden som er forsikret, men som ikke er part i avtalen. Typiske eksempler er ektefeller, medeiere og panthavere i den forsikrede gjenstand, hvor medforsikring er regulert i fal. § 7-1. Medforsikring vil da inntre automatisk når den ene ektefellen, medeieren eller eieren av en pantsatt gjenstand tegner forsikring. Automatisk medforsikring etter fal. kan fravikes i avtalen, ${ }^{22}$ men hvis den ikke er fraveket er slik medforsikring også selvstendig, dvs. at den medforsikrede er vernet mot en handling eller unnlatelse fra forsikringstaker eller sikrede som kan føre til at selskapet er helt eller delvis fri for ansvar etter reglene om opplysnings- og omsorgspliktene som er nevnt ovenfor. ${ }^{23}$ Dette betyr at medforsikrede kan ha et mer omfattende vern enn sikrede etter avtalen. Dersom sikrede bryter sine plikter, kan selskapet like fullt bli ansvarlig overfor den eller de medforsikrede.

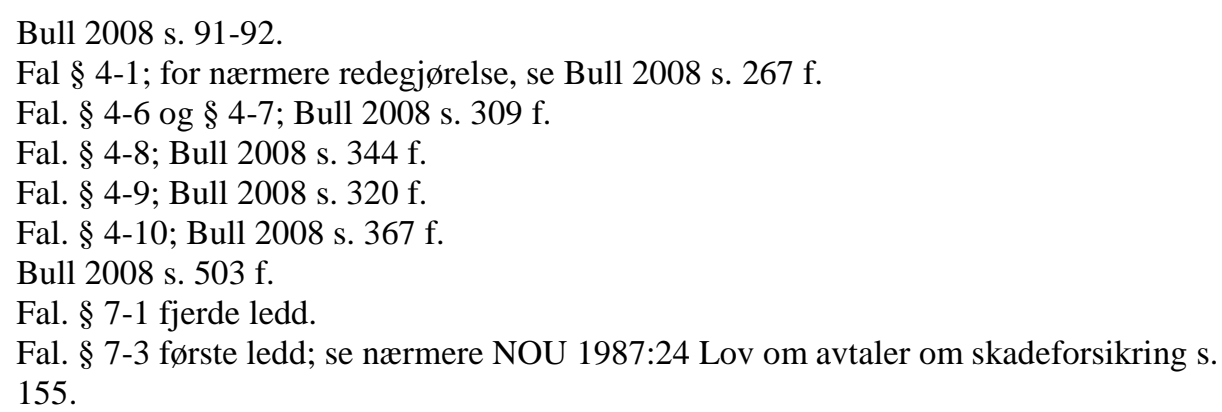


Utenfor området for automatisk medforsikring etter fal. må medforsikring avtales. ${ }^{24}$ Dette gjelder både spørsmålet om hvem som er medforsikret og hvilket vern denne medforsikrede skal ha mot forsømmelser begått av forsikringstaker eller sikrede. Hvis den medforsikrede ikke får større rett mot selskapet enn det forsikringstaker eller sikrede har, sier man at medforsikringen er uselvstendig og at den medforsikrede blir identifisert med sikrede. ${ }^{25}$ Hvis den medforsikrede beskyttes mot disse feilene, er medforsikringen selvstendig på linje med fal. og det blir ikke tale om identifikasjon. ${ }^{26}$

En fjerde aktør i forsikring er skadelidte i en erstatningssituasjon hvor skadevolder har ansvarsforsikring. Skadelidte er ikke part i ansvarsforsikringsavtalen, men har et krav på skadevolder som skadevolder kan kreve dekket under sin ansvarsforsikring. Etter fal. § 7-6 har skadelidte også et direkte krav mot skadevolderens ansvarsforsikring i den utstrekning skadevolderen er ansvarlig etter alminnelige erstatningsrettslige regler ${ }^{27}$ og ansvaret er omfattet av ansvarsforsikringen. ${ }^{28}$ Dette betyr at dersom sikrede/skadevolder bryter plikter i forsikringsavtalen, vil dette også ramme skadelidte. Det gjelder likevel et unntak fra denne regelen: Pliktbrudd som gjelder forhold etter at forsikringstilfellet har inntruffet, kan ikke påberopes overfor skadelidte. ${ }^{29}$ Tanken er at når forsikringstilfellet har inntruffet, tilhører kravet skadelidte, og hans stilling skal derfor ikke forverres av sikredes pliktbrudd. ${ }^{30}$ Ved tvungen ansvarsforsikring blir skadelidtes vern sterkere; I så fall kan selskapet ikke påberope seg innsigelser det kunne gjort gjeldende mot forsikringstaker eller sikrede. ${ }^{31}$ En tvungen ansvarsforsikring vil også fortsette å gjelde overfor skadelidte en måned etter at den er oppsagt i forhold til forsikringstaker. ${ }^{32}$

\section{Regress mot en ansvarlig skadevolder og hans ansvarsforsikring fra forsikring mot ting- og formueskade}

\subsection{Utviklingslinjer og utgangspunkter}

Et forsikringstilfelle som er dekket under en forsikring mot tingsskade eller formuestap kan være forårsaket av en tredjemann som er ansvarlig for skaden etter alminnelige erstatningsrettslige regler. Sikrede/skadelidte kan alltid kreve sitt tap dekket under egen

\footnotetext{
Fal. § 7-5.

Se f.eks. Nordic Marine Insurance Plan 2013 Version 2019 (NP) kap. 7 og 8.

Se f.eks. NP § 8-7.

Fal. § 7-6 fjerde ledd første punktum; Bull 2008 s. 550.

Fal. § 7-6 fjerde ledd andre punktum; Bull 2008 s. 551-553.

Fal. § 7-6 fjerde ledd andre punktum; Bull 2008 s. 551-553.

Bull 2008 s. 551-553.

Fal. § 7-7 annet ledd første punktum; Bull 2008 s. 553.

Fal. § 7-7 annet ledd annet punktum. Sikkerhetsstillelse for advokater gjelder 3 måneder etter at tilsynsrådet for advokater har fått melding om at sikkerhetsstillelsen er bortfalt, jf. advokatforskriften $\S 2-6$ tredje ledd.
} 
forsikring mot tingskade eller formuestap, C, og vil normalt gjøre det. Spørsmålet er da om C har rett til regress mot skadevolder. Det tradisjonelle utgangspunktet i forsikringsretten var at et slikt regresskrav krevde en begrunnelse og et rettslig grunnlag. ${ }^{33}$ Dette ble opprinnelig løst i praksis ved at selskapene tok inn en subrogasjonsklausul i vilkårene som sa at selskapet trådte inn i sikredes erstatningskrav mot tredjemann. I fal. 1930 - som i stor utstrekning kodifiserte forsikringspraksis - tok man så inn en regressklausul i $§ 25$. Den tidligere avtalefestede subrogasjon ble derfor erstattet med overdragelse i kraft av loven, eller legal cesjon. ${ }^{34}$

Ved en lovendring i $1985^{35}$ ble fal. $§ 25$ opphevet og regler om forsikringsselskapenes regress flyttet til skadeserstatningsloven ${ }^{36} \S 4-3$ jf. $§ 4-2$. I motsetning til fal. $1930 \S 25$ gir imidlertid de nye reglene ikke noen generell hjemmel for regress, men regulerer begrensning $\mathrm{i}$ regressretten som reflekterer begrensninger i skadelidtes rett til å kreve erstatning fra skadevolder i skl. § 4-2. I dag er det derfor ingen generell lovregel som hjemler regress for forsikringsselskapet mot en ansvarlig skadevolder. Spørsmålet om regress var imidlertid oppe i Høyesterett i Rt-1986-381 vedrørende et krav fra en tysk «krankenkasse» mot et norsk trafikkforsikringsselskap etter et trafikkuhell hvor den tyske sykekassen hadde dekket skadelidtes legebehandling, sykehusopphold og sykepenger. Selve utgangspunktet om hjemmel for regress mot skadevolder var ikke bestridt mellom partene og Høyesterett uttaler på s. 384:

«For Høyesterett har det som nevnt ikke vært bestridt at den som dekker en skadelidts tap, som utgangspunkt kan søke regress hos den som er ansvarlig for skaden. Dette er jeg enig i. Jeg viser til de tre høyesterettsdommer som er nevnt av den ankende part, særlig til dommen i Rt-196848 , der fire av de fem dommere bygget på at en pensjonskasse var trådt inn i skadelidtes krav ved en cessio legis».

Det ser derfor ut som den lovfestede hjemmelen for regress i skadeforsikring som opprinnelig lå i fal. 1930 § 25 nå er omgjort til en ulovfestet rett til legal cesjon basert på Høyesterettspraksis. ${ }^{37}$ Retten har hjemmel i rettspraksis og medfører at kravet overdras i sin helhet. Selskapet får imidlertid ikke større rett mot skadevolder enn det skadelidte har. Som nevnt innførte man ved opphevelsen av fal. 1930 § 25 regler om begrensning i skadelidtes rett til å kreve en ansvarlig skadevolder i skl. § 4-2 med tilhørende regler om begrensning i regressretten i § 4-3. Disse reglene behandles under punkt 3.2 og 3.3. Er skadelidtes krav ikke stengt av skl. § 4-2, er utgangspunktet derimot overdragelse i kraft av loven. Noen

\footnotetext{
Knut Selmer, Forsikringsrett, 1982 (Selmer 1982) s. 343.

Selmer 1982 s. 344.

21 juni 1985 nr. 81

Lov 13. juni 1968 nr. 26 om skadeserstatning (skl).

Jf. Viggo Hagstrøm og Are Stenvik, Erstatningsrett, 2015 (Hagstrøm og Stenvik 2015) s. 539-540, Jan Haugen, Innføring i forsikringsrett, 2000 s. 300, Bjørn Engstrøm, Skadeserstatningsloven med kommentarer, 2010, s. 190-191. Se også Ot.prp.nr.60 (19801981) Om lov om endringer i erstatningslovgivningen for så vidt gjelder lemping av erstatningsansvar, forsikringsgivers regressrett m m s. 43. Både Rt-1986-381 og Rt-196848 gjaldt regress etter dekning for personskade, men dette synes ikke å ha noen betydning.
} 
forsikringsavtaler inneholder likevel særlige subrogasjonsklausuler, jf. punkt 3.4. Andre forsikringsavtaler følger derimot løsningen i skl. § 4-3 ved å avskjære regress gjennom en såkalt knock-for-knock regulering, jf. punkt 3.5.

\subsection{Kanalisering etter skadeserstatningsloven $§ 4-2$ jf. $§ ~ 4-3$}

Skadeserstatningsloven $§ 4-2$ jf. § 4-3 regulerer skadevolderens stilling når skaden kan kreves dekket under en forsikring mot tingskade og annen formueskade:

§ 4-2. (skadevolderens stilling når skaden er dekket ved forsikring)

1. I det omfanget det er på det rene at en skade kan kreves dekket av forsikring for tingskade eller annen formuesskade, kan den skadelidte bare gjøre gjeldende sitt erstatningskrav mot den ansvarlige skadevolder dersom skaden er voldt:

a. ved forsett eller grov uaktsomhet av den ansvarlige selv, eller

b. i hans yrke, ervervsvirksomhet eller dermed likestilt virksomhet.

§ 4-3. (forsikringsselskapets regress for utbetalt erstatning)

I den utstrekning selskapet ved forsikring for tingskade eller annen formuesskade har betalt erstatning til skadelidte, kan det kreve regress hos den ansvarlige skadevolder så langt skadelidte kunne ha krevd erstatning hos skadevolderen etter § 4-2.

Det følger av § 4-3 at et forsikringsselskap som har betalt erstatning til skadelidte for tingeller formueskade, ikke kan kreve regress hos den ansvarlige skadevolderen i den utstrekning skadevolderen er beskyttet av bestemmelsen i $§ 4-2$. Spørsmålet er derfor hvor langt beskyttelsen av skadevolder etter $\S 4-2$ rekker.

Utgangspunktet etter skl. § 4-2 nr. 1 er at kanaliseringen til skadelidtes forsikring mot tingskade og formueskade er absolutt hvis en slik forsikring først er tegnet og omfatter den aktuelle skaden. ${ }^{38}$ Unntakene fra hovedregelen i bokstav a) og b) er imidlertid omfattende. Etter skl. § 4-2 nr. 1 bokstav a) gjelder utgangspunktet ikke når skaden er voldt ved forsett eller grov uaktsomhet av skadevolderen selv. Dette betyr at skadevolder kun kan påberope seg skadelidtes forsikring dersom skadevolder har utvist vanlig uaktsomhet eller er ansvarlig på objektivt grunnlag.

Videre følger det av skl. § 4-2 nr. 1 bokstav b) at skadevolder heller ikke er beskyttet dersom det dreier seg om skader voldt «i hans [det vil si skadevolderens] yrke, ervervsvirksomhet eller dermed likestilt virksomhet». Dette unntaket omfatter all skade voldt under utøvelse av næringsvirksomhet, herunder skader voldt av ansatte etter reglene om arbeidsgiveransvaret $\mathrm{i}$ skl. § 2-1. ${ }^{39}$ For transport- sjø og luftfartsforsikring i næringsvirksomhet er det uttrykkelig

38 NOU 1977:33 Om endringer i erstatningslovgivningen, s. 29.

39 Jf. f.eks. HR-2018-577-A om regressansvar mot en stiftelse som skadevolder. 
presisert i skl. § 4-4 nr. 1 bokstav a) at kanaliseringsbestemmelsen i $§ 4-2$ jf. $§ 4-3$ ikke gjelder.

Ytterligere unntak i kanaliseringsbestemmelsen følger av $§ 4-4 \mathrm{nr} .1$ bokstav b) for kreditt og garantiforsikring.

I praksis har det vært spørsmål om bestemmelsen medfører kanalisering av selgerens ansvar etter avhendingsloven til selgerens og/eller kjøperens boligforsikring. ${ }^{40}$ Konsekvensen av et slikt synspunkt er at kjøperen av en bolig ikke kan reise krav mot selgeren om prisavslag, utbedring eller erstatning etter avhendingsloven såfremt den aktuelle mangelen er dekket under selgerens eller kjøperens boligforsikring. Det følger imidlertid både av ordlyden og forarbeidene at skl. § 4-3 jf. § 4-2 ikke gjelder en tingskadeforsikring på skadevolderens - her selgerens - hånd, ${ }^{41}$ og det ville også være helt meningsløst om en tingsskadeforsikring på selgerens hånd med selgeren som sikrede skulle stenge kjøperen fra å reise et mangelskrav. Spørsmålet om bestemmelsene stenger kjøperen fra å reise krav mot selgeren etter avhendingsloven hvis kjøperen har egen boligforsikring er mer komplisert, men må antagelig besvares benektende. ${ }^{42}$ Det er ikke naturlig å karakterisere en kjøper og selger for skadelidte og skadevolder, og kjøperens krav etter avhendingsloven omfatter prisavslag, utbedring og heving, ikke bare erstatning. I så fall vil skl. § 4-3 jf. § 4-2 heller ikke stenge kjøperens boligforsikring fra regress mot selgeren.

\subsection{Situasjonen når skadevolder har ansvarsforsikring}

I den utstrekning skadelidte er avskåret fra å kreve dekning hos den ansvarlige skadevolderen etter skl. § 4-2, er også skadevolderens ansvarsforsikring beskyttet mot regresskrav fra skadelidtes forsikring mot tings- og formueskade. En ansvarsforsikring som dekker ansvaret for «den ansvarlige skadevolder» er derfor beskyttet mot regress så fremt skaden ikke er voldt ved grov uaktsomhet eller i næring. ${ }^{43}$

Bestemmelsene gjelder bare for krav som rettes mot «den ansvarlige skadevolder». Ifølge Rt1993-1018 gjelder den ikke regress fra tingskadeforsikringen mot trafikkforsikringen.

Høyesterett peker innledningsvis på at «det er tale om et regresskrav mot trafikkforsikreren, ikke mot den personlige skadevolder», og uttaler videre at

«[u]ttrykkene 'den ansvarlige skadevolder' og 'den ansvarlige selv' kan ikke uten vold mot naturlig språkbruk oppfattes til å omfatte et trafikkforsikringsselskap som i denne egenskap er forpliktet til å erstatte skade som en motorvogn gjør. [s. 1020]

$[\ldots]$

40 Wilhelmsen 2018 s. $119-120$ og s. 130-132.

$41 \quad$ Wilhelmsen 2018 s. 120 og note 47.

42 Wilhelmsen 2018 s. 130-132.

43 Eksempler på regress mot ansvarsforsikring ved grov uaktsomhet er HR-2017-1977-A

«Hårføner», HR-2017-958-A og Rt. 2004 s. 1942 «Kinaputt». 
Jeg tilføyer at når skaden er dekket både ved tingsforsikring og av trafikkforsikring, kan skadelidte utvilsomt velge hvilken av disse han vil kreve erstatning av. Når regressen mot trafikkforsikringen fortsatt består, innebærer det at skadelidtes valg ikke får betydning for hvor tapet endelig skal plasseres. Trafikkskadene vil således fortsatt bæres av det trafikkollektiv som etter bilansvarslova skal erstatte skader som motorvogner gjør, også når skaden dekkes av en tingsforsikring.» [s. 1020-1021]

Resultatet av dommen er at «den ansvarlige skadevolder» etter skl. § 4-2 og § 4-3 ikke omfatter trafikkforsikringens ansvar etter bal. $\S 4$. Dette gjelder selv om skadevolderen etter bal. $\S 11$ har et personlig ansvar etter alminnelige erstatningsrettslige regler når regresskravet er rettet mot trafikkforsikringen.

Regressretten er heller ikke avskåret for skade voldt i næringsvirksomhet. Forholdet mellom en boligforsikring og boligselgerforsikringen faller antagelig også utenfor $\S 4-2$ jf. $\S 4-3$, jf. ovenfor under 3.2.

\subsection{Subrogasjonsklausuler}

En subrogasjonsklausul medfører at selskapet trer inn i sikredes rett mot en ansvarlig tredjemann, og stemmer derfor med det ulovfestede utgangspunktet om legal cesjon. En slik klausul kan ikke anvendes i strid med reglene i skl. § 4-2 jf. § 4-3; det er klart at selskapet og sikrede ikke i sin avtale kan frata skadevolder rettigheter han har etter skl. ${ }^{44}$ Men har skadevolderen voldt skaden i yrke eller næringsvirksomhet er han ikke beskyttet. Det følger også uttrykkelig av skl. § 4-4 nr. 1 bokstav a) at bestemmelsene ikke gjelder transport-, sjøog luftfartsforsikring for næringsvirksomhet. I sjø- og transportforsikring har man lang tradisjon for at kaskoforsikring og tidstapforsikring kontraktsfester rett til regress mot skadevolder. Regelen i NP lyder som følger. ${ }^{45}$

§ 5-13. Assurandørens rett til å tre inn i dekningskrav som sikrede har mot tredjemann Kan sikrede forlange at tredjemann erstatter tapet, inntrer assurandøren ved utbetalingen av erstatningen i sikredes rett mot tredjemann. Regelen i § 4-14 får tilsvarende anvendelse.

Svarer assurandøren bare delvis for tapet, deles kravet forholdsmessig mellom assurandøren og sikrede. Det samme gjelder hvis erstatning for det fulle tap ville bli betalt med et høyere beløp av tredjemann enn av assurandøren, men tredjemann bare hefter for en andel av tapet eller hele tapsbeløpet ikke kan inndrives.

Hvis assurandørens krav utbringer et høyere nettobeløp enn det han har betalt til sikrede med tillegg av renter, tilfaller det overskytende sikrede.

Selskapet har derfor krav om regress så langt skadevolder er ansvarlig for skaden. Dersom selskapet bare er delvis ansvarlig for tapet eller skadevolder hefter med et høyere beløp enn selskapet, skal kravet deles forholdsmessig mellom selskapet og sikrede. Sikrede har også

44 Wilhelmsen 2018 s. $133-134$.

45 Se tilsvarende i Vilkår for transportforsikring av varer 1995 versjon $2004 \S 53$. 
krav på overskuddet om kravet mot skadevolder utbringer et høyere beløp enn det selskapet har betalt til sikrede.

\subsection{Kanalisering ved knock for knock reguleringer}

En knock for knock regulering betyr i korthet at en skade blir der den rammer. En slik regulering har lang tradisjon i kontrakter knyttet til prosjekter og samarbeid i offshore sektoren. ${ }^{46}$ Denne teknikken brukes f.eks. i Norsk Fabrikasjonskontrakt 2015 og Norsk Totalkontrakt 2015, hvor man har etablert en systematisk regulering av ansvar og forsikring hvor kjernen er at all skade blir der hvor den rammer innenfor kontraktspartenes definerte risikosoner tvers gjennom hele kontraktspyramiden og kanaliseres til skadelidtes forsikringer. ${ }^{47}$ Begrunnelsen er at partene i et slikt prosjekt eller samarbeide har en gjensidig risiko for å skade hverandres $\varnothing$ konomiske interesser - typisk hvor flere leverandører arbeider sammen om bygging av en offshore installasjon. Den gjensidige skaderisikoen følger av tett samarbeid over lengre tid og med en sammenblanding av personer og gjenstander som kan bli skadet. Ofte er det også stor risiko for skade fordi prosjektene er kompliserte og kan være utsatt for betydelig klima risiko. Partene er imidlertid ikke interessert i ressurskrevende erstatningsrettslige tvister som trekker oppmerksomhet bort fra prosjektsamarbeidet og som også kan føre til gnisninger dem imellom. ${ }^{48}$ Partene avtaler derfor at enhver deltager dekker skader på egne interesser selv om skadene er voldt av en skadevolder som er deltager $\mathrm{i}$ prosjektet. ${ }^{49}$ Partene har også en gjensidig plikt til å forsikre sine egne økonomiske interesser ${ }^{50}$ Hensikten er derfor at skade på partenes $\emptyset$ konomiske interesser skal kanaliseres til skadelidtes egen forsikring mot tingskade og formueskade. ${ }^{51}$

En slik kanalisering er i tråd med prinsippet i skl. § 4-2 jf. § 4-3, men kanaliseringen etter disse bestemmelsene gjelder ikke skadevolder i næringsvirksomhet. Et forsikringsselskap som har betalt erstatning til en deltagende skadelidt har derfor i utgangspunktet adgang til regress mot en deltagende skadevolder basert på legalcesjon, jf. ovenfor i punkt 3.1. En slik regressrett vil imidlertid hindre gjennomføringen av knock for knock prinsippet. Partene har derfor også ifølge avtalene en plikt til å sørge for at forsikringsavtalene som tegnes har klausuler som stenger regressretten. Dette gjøres på to forskjellige måter:

46 Se nærmere Knut Kaasen, Tilvirkningskontrakter, 2018 (Kaasen 2018) Del VIII; TrineLise Wilhelmsen, Liability and insurance clauses in contracts for vessel services in the Norwegian offshore sector - the knock for knock principle, SIMPLY 2012 (Wilhelmsen 2012) s. 81-111; Bull 1988 Del IV.

$47 \quad$ Kaasen 2018 s. 768-772; Wilhelmsen 2012 s. 87-93.

$48 \quad$ Kaasen 2018 s. 765-767; Wilhelmsen 2012 s. 95-96.

49 F.eks. Norsk Fabrikasjonskontrakt 2015 (NF) og Norsk Totalkontrakt 2015 (NTK) art. 30; Kaasen 2018 s. 799 f.; Wilhelmsen 2012 s. 87-88.

$50 \quad$ NF/NTK art. 31, Kaasen 2018 s. 827 f.; Wilhelmsen 2012 s. 93-95.

$51 \quad$ Kaasen 2018 s. 767; Wilhelmsen 2012 s. 83. 
Det enkleste er at avtalepartene har plikt til å sørge for at forsikringsavtalen inneholder en regressfraskrivelsesklausul. ${ }^{52}$ I så fall gir selskapet fra seg den retten til regress som følger av ulovfestede regler om legalcesjon.

En mer komplisert fremgangsmåte er at forsikringsselskapet og den aktuelle prosjektdeltager som sikrede avtaler at en eller flere andre deltagere i prosjektet skal være medforsikret under sikredes avtale. ${ }^{53}$ At en part er medforsikret betyr i utgangspunktet bare at hans $\varnothing$ konomiske interesser i den forsikrede gjenstand er omfattet av forsikringen, jf. ovenfor under pkt. 2. Dette er ikke poenget her. Medforsikring innebærer nemlig også en såkalt «indirekte ansvarsforsikring». ${ }^{54}$ En slik indirekte ansvarsforsikring innebærer at medforsikrede har samme beskyttelse mot forsikringsselskapet som han ville hatt som «hovedsikrede» om han var ansvarlig for fremkallelsen av et forsikringstilfelle gjennom brudd på omsorgsreglene. ${ }^{55}$ Hvis medforsikrede volder skaden ved vanlig uaktsomhet er han derfor beskyttet mot et regressansvar fra forsikringsselskapet. Det samme gjelder ved brudd på sikkerhetsforskrifter med mindre han har vært mer enn lite å laste.

Regressfraskrivelse i slike avtaler gjelder gjerne uansett skyldgrad hos skadevolder. De reiser derfor spørsmål om hvor langt slike avtaler er gyldige. Dette spørsmålet forfølges ikke nærmere her. ${ }^{56}$

\section{Regress mellom to ansvarsforsikringer}

Hvis to skadevoldere er ansvarlig for samme skade, hefter de solidarisk etter skl. § 5-3 om «skade voldt av flere»:

1. Flere som plikter å betale erstatning for samme skade, svarer en for alle og alle for en. Det samme gjelder flere som plikter å betale oppreisning for samme skade, krenking eller mislige atferd, dersom ikke retten bestemmer annet.

2. I hvilken utstrekning den som har betalt erstatning eller oppreising kan gjøre krav gjeldende mot andre ansvarlige, avgjøres under hensyn til ansvarsgrunnlaget og forholdene ellers.

Annet ledd bestemmer også et evt. etterfølgende regressoppgjør mellom disse. Hvis begge skadevoldere har ansvarsforsikring, er det spørsmål om bestemmelsen også regulerer regressoppgjøret mellom selskapene. Bestemmelsen gjelder ifølge rettspraksis ${ }^{57}$ og teori ${ }^{58}$

$52 \quad \mathrm{NF} / \mathrm{NTK}$ art. 31.1 tredje ledd og 31.2 tredje ledd.

$53 \quad$ NF 2015 art. 31.1 tredje ledd.

54 Se nærmere Wilhelmsen 2012 s. 94-95; NOU 1987:24 s. 145, jf. s. 151-152; Bull 2008 s. 539-540; Bull 1988 s. 484 f.

55 NOU 1987:24 s. 145, jf. s. 151-152; Bull 2008 s. 539-540; Wilhelmsen 2012 s. 94-95.

$56 \quad$ Se Kaasen 2018 s. 776-785; Wilhelmsen 2012 s. 102-111.

57 Rt-2005-870 avsnitt 40.

58 Askeland 2005 s. 4-6; men motsatt hos Harald Benestad Anderssen, Avhendingsloven med kommentarer, Oslo, 2008 (Anderssen 2008) s. 401. 
ikke kontraktsansvar. Det er like fullt antatt at bestemmelsen kommer til anvendelse på tilsvarende måte som i det underliggende erstatningsforholdet. ${ }^{59}$ Uansett er det lagt til grunn at bestemmelsen må anvendes analogisk når flere hefter for samme skade ifølge kontrakt. ${ }^{60}$ Ansvaret skal i så fall fordeles etter de hensyn som bestemmelsen nevner. Bestemmelsen refererer til «ansvarsgrunnlaget» og åpner for at man kan ta preventive hensyn. Skl. § 5-3 nr. 2 refererer videre til «forholdene ellers», hvor man legger vekt på årsaksforløpet. ${ }^{61}$

Bestemmelsen gjelder antagelig bare hvor det er to forskjellige skadevoldere og ikke hvor samme skadevolder har to kolliderende ansvarsforsikringer. I denne situasjonen er det mer nærliggende å bruke reglene om dobbeltforsikring, jf. nedenfor.

En særlig variant av spørsmålet om regress mellom to ansvarsforsikringsselskaper er regress mellom boligselgerforsikringen og en ansvarsforsikring hvor selger hefter solidarisk med f.eks. en megler eller takstmann for gale opplysninger i prospektet eller taksten. Som nevnt ovenfor er det tvilsomt hvordan boligselgerforsikringen skal kategoriseres fordi den ikke bare dekker selgerens erstatningsansvar etter avhl., men også prisavslag, retting og heving. Forsikringsformen reiser derfor betydelige problemer i forhold til reglene i skl. § 4-2 jf. § 4-3 og også i andre sammenhenger hvor kategoriseringen av forsikringen har betydning.

Et spørsmål gjelder bruk av subrogasjonsklausuler. I boligselgerforsikring er det ikke uvanlig at man har tatt inn en subrogasjonsklausul som sier at boligselgerforsikringen trer inn i selgerens krav mot en ansvarlig tredjemann. ${ }^{62}$ Dette ville i så fall medføre at hele tapet veltes over på den ansvarlige tredjemann. Det må imidlertid legges til grunn at en slik klausul ikke kan frata tredjemann den beskyttelse han i utgangspunktet måtte ha i regressomgangen etter skl. $\S 5-3 \mathrm{nr} .2$, som legger opp til en fordeling av tapet.

Et annet spørsmål gjelder forholdet mellom adgangen til regress og et direkte erstatningskrav mot skadevoldende tredjemann/dennes ansvarsforsikrer. Problemet illustreres av Rt-20081078 og Rt-2015-556. Begge sakene gjaldt et boligsalg hvor det pga. uaktsomhet fra takstmannen var gitt gale opplysninger i taksten, og dette resulterte i et krav om prisavslag fra kjøperen som ble dekket av boligselgerforsikringen. Boligselgerforsikringen søkte deretter sin utbetaling dekket fra takstmannens ansvarsforsikring bl.a. på grunnlag av direktekrav for informasjonsansvar og fikk medhold i Høyesterett. Selv om dommene er begrunnet med at boligselgerselskapet har et selvstendig erstatningskrav mot takstmannens ansvarsforsikrer for

$59 \quad$ Bull 2008 s. 462.

60 Jf. f.eks. Rt-2005-870 avsnitt 40; se nærmere Bjarte Askeland, Skadelidtes valgrettperspektiver på Meglerdommen Rt 2005 s. 870, Norsk Forsikringsjuridisk forenings Publikasjoner, 2005 nr. 82 (Askeland 2005) s. 6 f.; Viggo Hagstrøm, Obligasjonsrett, 2011 (Hagstrøm 2011) s. 713-715; Hagstrøm og Stenvik 2015 s. 534-540.

61 Hagstrøm og Stenvik 2014 s. 537; Trine-Lise Wilhelmsen og Birgitte Hagland, Om erstatningsrett, 2017 (Wilhelmsen og Hagland 2017) s. 374.

62 Wilhelmsen 2018 s. 126 
gal informasjon, kan det argumenteres med at det i realiteten dreier seg om et regressansvar. ${ }^{63}$ I så fall burde det vært foretatt en ansvarsfordeling etter skl. § 5-3 nr. 2.

\section{Dobbeltforsikring}

\subsection{Noen utgangspunkter}

Dobbeltforsikring er regulert i fal. § 6-3. Bestemmelsen er preseptorisk til fordel for sikrede, jf. fal. § 1-3, og lyder som følger:

\section{§ 6-3. (tapet dekkes av flere forsikringer)}

Dekkes samme tap av flere forsikringer, kan sikrede velge hvilke forsikringer han eller hun vil bruke, inntil sikrede har fått den erstatning han eller hun i alt har krav på.

Er flere selskaper ansvarlige for sikredes tap etter første ledd, utliknes erstatningen forholdsmessig mellom selskapene etter omfanget av det enkelte selskaps ansvar for tapet, når ikke annet er avtalt mellom selskapene.

Det følger av første ledd at dersom det foreligger dobbeltforsikring, har sikrede rett til å velge hvilket selskap han vil reise kravet mot. Dobbeltforsikring skal imidlertid ikke medføre at sikrede får mer enn dekning for det tap han har lidt. Han kan derfor ikke kreve full dekning fra flere selskaper, men må nøye seg med oppgjør etter de vilkårene som vil gi ham best erstatning. ${ }^{64}$

Dersom det foreligger dobbeltforsikring, skal erstatningen utlignes forholdsmessig mellom selskapene etter omfanget av det enkelte selskaps ansvar for tapet, når ikke annet er avtalt mellom selskapene, jf. annet ledd. Dette betyr at det ikke spiller noen rolle for tapsfordelingen mellom selskapene hvilket selskap sikrede i første omgang retter kravet mot; tapet skal i regressomgangen fordeles mellom dem etter omfanget av deres respektive ansvar.

Hensikten med fal. § 6-3 er ifølge forarbeidene å unngå subsidiaritetsklausuler. ${ }^{65}$ Slike klausuler kan være ulikt formulert, men det sentrale er at sikrede bare kan gjøre krav gjeldende under vedkommende forsikring dersom han ikke får dekning under en annen forsikring som han har tegnet. ${ }^{66}$ En slik klausul er ikke gyldig etter fal. § 6-3, som klart uttrykker at dersom forsikringene dekker «samme tap», skal sikrede kunne velge. ${ }^{67}$

63 Jan-Ove Færstad, Regressoppgjør i erstatningsrettslige klar: En kommentar til

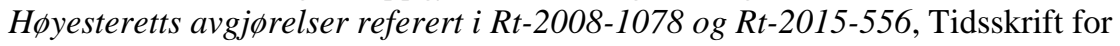
Erstatningsrett, forsikringsrett og trygderett, 2016 (Færstad 2016) s. 97-120 på s. 111-112 og s. 116 f.; se også Hagstrøm og Stenvik 2015 s. 540.

64 Jf. NOU 1987: 24 s. 121.

65 NOU 1987: 24 s. 122.

66 Bull 2008, s. 462.

67 Jf. også Ot.prp. nr. 49 (1988-1989) s. 75. 
Innenfor området for fal. § 6-3 kan man heller ikke avtale subrogasjonsklausuler som gir selskapet anledning til å tre inn i sikredes krav mot et annet forsikringsselskap. Det fremgår av forarbeidene til fal. $\S 6-3$ at selskapene fritt kan bestemme avvikende regressoppgjør dem mellom, men at lovens regel om regressoppgjør ikke kan fravikes i den enkelte forsikringsavtale. ${ }^{68}$

Bestemmelsen gjelder kun samme «sikrede» og «samme tap», se pkt. 5.2. Den reiser også spørsmål om forholdet mellom selskapets rett i regressomgangen mot annet selskap og sikredes underliggende rett mot dette selskapet, se pkt. 5.3.

\subsection{Samme sikrede og samme tap}

Bestemmelsen forutsetter at det er samme «sikrede» som har rett til dekning under begge forsikringer. ${ }^{69}$ Den gjelder derfor hvor samme forsikringstaker/sikrede har tegnet flere forsikringer som overlapper hverandre. En slik situasjon kan oppstå hvor man tegner selvstendig reiseforsikring samtidig som man betaler reisen med et kredittkort hvor reiseforsikring automatisk er inkludert som tilleggsytelse. Dobbeltforsikring kan også oppstå hvis man har kombinert forsikring som omfatter bolig med innbo etc. og separat verdisakforsikring for smykker og andre særlig verdifulle gjenstander. Bestemmelsen må antagelig også gjelde hvor samme sikrede har flere ansvarsforsikringer som dekker samme deler av et erstatningskrav.

Derimot gjelder bestemmelsen ikke hvor flere sikrede under samme forsikring har krav på erstatning for hver sin del av et økonomisk tap. Hvis en boligforsikring dekker både eieren av boligen og banken som panthaver har panthaveren dekning for lånet mens eieren har dekning for resten av boligens verdi. Dette er ikke dobbeltforsikring.

Bestemmelsen gjelder heller ikke ved overlapping mellom flere ansvarsforsikringer med hver sin sikrede skadevolder. Her skal samme tap dekkes av to forskjellige sikrede. I slike tilfeller gjelder skl. § 5-3, jf. ovenfor. Det er heller ikke dobbeltforsikring hvor det er overlapping mellom en ansvarsforsikring på skadevolderens hånd og en tingsforsikring på skadelidtes hånd. Også i denne situasjonen er det to forskjellige sikrede. Dette gjelder selv om skadelidte har et direkte krav mot skadevolderens forsikring etter fal. § 7-6, slik at skadelidte både kan kreve tapet dekket under sin tingsforsikring og under skadevolderens ansvarsforsikring. Skadelidte har likevel ikke status som «sikrede» under ansvarsforsikringen. ${ }^{70}$

Det må videre legges til grunn at det heller ikke er dobbeltforsikring hvor boligselgerforsikringen med selgeren som sikret overlapper kjøperens boligforsikring hvor

$68 \quad$ NOU 1987:24 s. 128.

69 Bull 2008 s. 459; Brynildsen, Lid \& Nygård, Forsikringsavtaleloven med kommentarer, 2014 (Brynildsen, Lid \& Nygård 2014) s. 229-230.

$70 \quad$ Bull 2008 s. 462; Brynildsen, Lid \& Nygård 2014 s. 230. 
kjøper er «sikrede», og heller ikke hvor boligselgerforsikringen overlapper selgerens boligforsikring hvis kravet tilkommer kjøper som medforsikret. ${ }^{71}$ Antagelig må det samme gjelde hvor boligselgerforsikringen overlapper selgerens boligforsikring. Selv om selgeren her er «sikrede» under begge forsikringer, tilkommer kravet under boligselgerforsikringen kjøperen. ${ }^{72}$ Det avgjørende er likevel at det her antagelig ikke foreligger «samme tap», jf. nedenfor.

Fal. § 6-3 gjelder videre to forsikringer som dekker «samme tap». Det må derfor foreligge et «tap» som dekkes to ganger. Begrepet «tap» refererer i utgangspunktet til et $\varnothing$ konomisk beløp og ikke til årsaken til tapet. Begrepet «dobbeltforsikring» forutsetter imidlertid at dekning to ganger gir sikrede en gevinst, og dette betyr at det økonomiske beløpet må være knyttet til samme skade eller forsikringstilfelle. Et eksempel er tap av bagasje som dekkes under to reiseforsikringer eller tyveri av verdisaker som både dekkes av verdisakforsikring og forsikring av innbo.

Antagelig må formuleringen «samme tap» også forstås slik at den refererer til samme $\emptyset$ konomiske «interesse». ${ }^{73}$ Begrepet «interesse» i forsikringsretten har sin bakgrunn i en tanke om at gjenstanden for forsikring ikke var det objektet som ble forsikret, men sikredes $\emptyset$ konomiske interesse i gjenstanden. Man sondrer da mellom objektiv kapitalinteresse, interesse knyttet til inntjening av en gjenstand, og interessen i å unngå et erstatningskrav. Denne sondringen er særlig relevant ved overlapping mellom selgerens boligforsikring og selgerens boligselgerforsikring, hvor man kan argumentere med at det foreligger to forskjellige interesser: selgerens boligforsikring omfatter den objektive kapitalverdien av boligen mens boligselgerforsikringen omfatter risikoen for å få et misligholdsansvar etter avhendingsloven. ${ }^{74}$

\subsection{Sikredes valgrett som forutsetning for selskapets rett til regress}

Fal. § 6-3 sier at «sikrede kan velge» hvilken forsikring han vil bruke dersom samme tap dekkes av flere forsikringer. Bestemmelsen forutsetter derfor at sikrede har et krav mot begge forsikringene. Om sikredes avtale mot det ene selskapet er bortfalt, tilsier ordlyden at bestemmelsen ikke kommer til anvendelse. Grunnlaget for bortfallet av avtalen er i utgangspunktet irrelevant; hvis kravet er bortfalt pga. svik under avtaleinngåelsen, risikoendringer, preklusjon/foreldelse eller oppsigelse, kan sikrede ikke lenger «velge» å reise kravet mot denne forsikringen. I en slik situasjon har det aktuelle selskapet heller ikke noe «ansvar for tapet» som kan utlignes i regressomgangen, jf. annet ledd. Et eksempel på spørsmål om det forelå dobbeltforsikring ved oppsigelse av avtalen er Rt-1989-583, hvor det ene selskapet hevdet at forsikringen deres var annullert:

Wilhelmsen 2018 s. 119.

Wilhelmsen 2018 s. 121-122.

Se nærmere Wilhelmsen 2018 s. 122-123.

Wilhelmsen 2018 s. 122-124. 
Sikrede var forsikret i selskap A, som krevde premieforhøyelse pga. feiltariffering, sendte premievarsel på tillegget og annullerte forsikringen da premien ikke ble betalt. I mellomtiden forhandlet sikrede med selskap B. Sikredes eiendom brant etter at B hadde gitt bindende tilsagn om avtale, men hvor endelig avtale ikke forelå. B følte seg bundet av tilsagnet og erstattet skaden. $\mathrm{B}$ krevde deretter regress på halve beløpet fra $\mathrm{A}$ etter fal. § 6-3 fordi det mente avtalen med A fortsatt var bindende på skadetidspunktet. Høyesterett ga B medhold. Sikrede hadde ikke annulert forsikringen med A og A hadde innrømmet at det ikke hadde hjemmel til ensidig å annulere avtalen.

B valgte her å gjøre opp på bakgrunn av sitt avtaletilsagn, men Bs hensikt var at avtalen egentlig skulle starte senere. Den naturlige løsningen her hadde vært at A dekket skaden ut fra sin avtale, mens B’s avtale begynte å løpe senere, altså slik at B ikke krevde premie før avtalen med A var opphørt. Det må da i hvert fall være riktig at B kunne kreve regress etter reglene om dobbeltforsikring.

Også i en nylig avsagt dom i Sunnmøre Tingrett 16.7.2018 konkluderte retten med at det forelå dobbeltforsikring: ${ }^{75}$

Her var situasjonen at sikrede sa opp avtalen med selskap A og flyttet forsikringen til selskap B. Ved en feil fra A ble det likevel sendt faktura for fortsatt forsikring til sikrede, og ved en feil hos sikrede ble fakturaen betalt. Feilen ble ikke oppdaget før etter 3 år, og i mellomtiden hadde det skjedd en omfattende skade som sikrede krevde dekket hos B. B krevde deretter regress hos A etter reglene om dobbeltforsikring. Da sikrede oppdaget feilen krevde han premien tilbake fra A, som først tilbydde tilbakebetaling av halve beløpet fordi det var feil på begge sider, men senere aksepterte å returnere hele premiebeløpet.

Retten konkluderer med at bindende avtale var inngått, men at begge partene hadde inngått den på grunnlag av bristende forutsetninger. Retten anfører at løsningen «kan forankres i» Rt-1989583 ved at man ikke trenger å påvise en ordinær forsikringsavtale for å anvende reglene om dobbeltforsikring, men at ansvar også kan oppstå på annet grunnlag.

Dommens resonnement er etter mitt syn overraskende. For at sikrede skal kunne kreve dekning under en forsikring, må det foreligge en bindende forsikringsavtale. I dette tilfellet forelå det en faktura som ble betalt for den perioden hvor skaden inntraff, men det var enighet mellom partene om at både fakturaen og betalingen berodde på en feil. Etter min oppfatning er det vanskelig å se at det her forelå en «partsvilje» hos noen av partene som kunne medføre at det var inngått en bindende avtale. Sikredes «vilje»var å flytte forsikringen til et annet selskap, og da de oppdaget feilen krevde de tilbakebetaling av premien. A skulle ha betalt hele premien tilbake siden det var A som i første rekke gjorde feilen. Men selv om den første beslutningen hos A var feil, kan jeg ikke se at denne feilen medfører at avtalen med sikrede blir bindende når sikrede har valgt å holde seg til en annen forsikring og å kreve full refusjon av premie. 
Det er også vanskelig å forstå referansen til bristende forutsetninger, som betyr at forutsetningene for avtalen brister etter at avtalen er inngått. Her var situasjonen at avtalen var oppsagt, men ble videreført ved en feil. Jeg ser dette som uriktige forutsetninger eller at det forelå en gjensidig villfarelse. Avtalen blir i så fall ugyldig fra videreføringstidspunktet. ${ }^{76}$ Heller ikke argumentet om at Rt-1989-583 viser at man ikke trenger å påvise en ordinær forsikringsavtale for å anvende reglene om dobbeltforsikring er overbevisende. I Rt-1989-583 var poenget at forsikringsavtalen med $\mathrm{A}$ ikke var annullert på skadetidspunktet, og da forelå det en «ordinær» forsikringsavtale.

Resultatet fremstår heller ikke som rimelig. Fal. § 6-3 annet ledd om regress mellom selskapene gir en rimelig regel hvis man forutsetter at det er to bindende avtaler. Hvis begge er bundet, er det ingen grunn til at kreditor gjennom sitt valg skal bestemme fordelingen mellom flere debitorer, jf. forarbeidenes kommentar om at «[s]ikredes valg av selskap bør ikke være avgjørende for den endelige plassering av ansvaret». ${ }^{77}$ Noen annen begrunnelse for bestemmelsen er ikke gitt. Men et forsikringsselskap A som har mottatt full premie for en forsikring har i utgangspunktet ingen berettiget forventning om at deler av oppgjøret overfor sikrede skal kunne hentes inn hos et annet selskap B. Tvert om vil en slik løsning gi selskap A en helt tilfeldig fordel. Løsningen er heller ikke til fordel for sikrede, fordi man da forutsetter at begge avtaler er bindende og at han ikke har rett til å kreve premien tilbake hos det selskapet hvor faktura og betaling berodde på en feil.

I den aktuelle tingrettsdommen var situasjonen også at sikredes krav mot det tidligere selskapet B ikke var meldt i tråd med fal. § 8-5, som sier at sikrede mister sitt krav om det ikke meldes innen et år. Sikrede hadde derfor ikke noe krav mot B, og kunne ikke «velge» å gå på B. Etter ordlyden i fal. § 6-3 blir det da heller ikke noe spørsmål om regress. Dommen bygger imidlertid ikke på regresshjemmelen i fal. § 6-3, men på at reglene om meldefrist i fal. $\S 8$-5 er rettet mot «sikrede» og ifølge HR-2017-2414-A ikke gjelder regresskrav mellom forsikringsselskaper. HR-2017-2414-A gjaldt imidlertid spørsmålet om regress fra selskap A mot selskap B fordi selskap A hadde dekket en skade som A mente skulle henføres til Bs forsikring. As utbetaling bygget altså på en rettsvillfarelse ved at A hadde betalt et krav $\mathrm{A}$ ikke var ansvarlig for, og som skulle dekkes av B. Dette er etter min mening en helt annen regress situasjon enn dobbeltforsikring.

I HR-2017-2414-A anførte B at A ikke fikk større rett mot B enn sikrede ville hatt, og sikrede hadde oversittet meldefristen i fal. § 8-5. Høyesterett kom til at skaden skulle henføres til A's forsikring, men kommenterte likevel spørsmålet om regress i avsnitt 52-56:

«Et sentralt utgangspunkt er her at bestemmelsen er utformet for å ivareta oppgjørsinteressen hos selskapet i normaltilfellene der sikrede fremmer sitt krav mot rette selskap med sikte på

76 Lilleholt 2017 s. 404; Jo Hov og Alf Petter Høgberg, Alminnelig avtalerett, 2009 (Hov og Høgberg 2009) s. 301.

$77 \quad$ NOU 1987: 24 s. 128. 
ordinært oppgjør. Den er ikke skrevet med regress mellom selskap for øyet, og ivaretar i en slik situasjon heller ikke de samme oppgjørshensyn.

Bestemmelsen gjelder uansett ikke for direktekrav fra skadelidte, jf. fal § 7-6 fjerde ledd hvor det fremgår at selskapet ved ansvarsforsikring ikke kan gjøre gjeldende overfor skadelidte at sikrede ikke har gitt melding etter $\S 8-5$. Overfor skadelidte har altså selskapet ansvar, selv om det skulle ha falt bort overfor sikrede. Det ville gi nokså tilfeldige resultater om regressadgangen var avhengig av om oppgjør hadde skjedd overfor sikrede eller direkte overfor skadelidte.

Jeg peker videre på at den løsningen Protector tar til orde for, lett ville sperre for regress $\mathrm{i}$ forsikringsforhold i situasjoner som i saken her, siden sikrede ofte ikke vil ha noen egentlig oppfordring til å melde skaden til andre enn det selskapet hvor han nå er forsikret. Avskjæring av regressadgangen på grunn av manglende melding fra sikrede kan medføre at et selskap endelig måtte bære et utlegg som rettelig skulle vært dekket av et annet selskap.

Endelig nevner jeg, som jeg også var inne på i omtalen av Mofrakt-dommen, at regressadgang uavhengig av fristregelen i § 8-5 formentlig kan bidra til at uenighet mellom selskapene løses uten at sikrede trekkes inn.

Konklusjonen er etter dette at et forsikringsselskap ikke kan gjøre gjeldende innsigelser etter fal $\S 8-5$ overfor et annet selskaps regresskrav».

Konklusjonen er helt generell, og tilsier at fal. § 8-5 ikke gjelder noen tilfeller av regress mellom forsikringsselskaper. Argumentasjonen gir etter min mening ikke dekning for en så generell konklusjon. Regress mellom to selskap fordi det ene selskapet ved en feil har betalt noe som egentlig skulle være dekket under en annen forsikring, er en helt annen situasjon enn dobbeltforsikring. Ved feilbetaling har A betalt noe som han ikke er ansvarlig for, men hvor ansvaret ligger hos B. Det dreier seg som retten sier om en tvist mellom selskapene hvor sikrede ikke er involvert fordi han har mistet retten til å gå på B pga. oversittelse av fristen. Ved dobbeltforsikring er begge selskaper ansvarlig og sikrede har direkte interesse i forhold til begge selskaper fordi han har krav på oppgjør etter de reglene som gir høyest utbetaling. Dommen gjaldt videre ansvarsforsikring hvor skadelidte hadde kravet mot B i behold selv om sikrede hadde tapt sitt. Reglene i fal. § 6-3 gjelder ikke ansvarsforsikring, slik at dette argumentet gjelder ikke dobbeltforsikring.

Retten legger videre vekt på at de oppgjørshensyn som ligger bak fal. § 8-5 ikke gjør seg gjeldende ved regress mellom to selskaper. Dette er kanskje riktig ved feilutbetalinger som presumptivt ikke skjer så ofte. Dobbeltforsikring er derimot relativt vanlig, og her må det være et hensyn for selskapene å få en avklaring innen rimelig tid.

Retten anfører videre at en annen løsning ville medføre avskjæring av regress i mange tilfeller fordi sikrede ikke har noen oppfordring til å melde kravet til andre enn selskapet som har forsikring på skadetidspunktet. Det er imidlertid ikke vanskelig for selskapet å sjekke dette under oppgjøret og sørge for at det andre selskapet får beskjed. Selskapene har ofte spørsmål 
om dobbeltforsikring i skadeoppgjørskjemaene. ${ }^{78}$ Etter min mening gir derfor den interesseavveining Høyesterett her foretar ikke grunnlag for at konklusjonen kan overføres til dobbeltforsikringssituasjonen.

\section{Regress mot annet selskap ved feil utbetalinger}

Hvis sikrede har flere suksessive forsikringer kan det tenkes at et selskap A dekker en skade i den tro at den er omfattet av As forsikringsavtale, men hvor det senere viser seg at skaden $\mathrm{i}$ realiteten var dekket under en annen forsikring, B. I så fall må utgangspunktet være at A har regress mot B, jf. Rt-1997-1029 (Mofrakt), hvor Høyesterett uttaler

«... Her vil jeg peke på at det følger av alminnelige rettsgrunnsetninger at den som har dekket en annens forpliktelse, normalt og som utgangspunkt, har et regresskrav i behold. Det er avskjæring av regress som krever særskilt hjemmel». ${ }^{79}$

Spørsmålet var oppe i HR-2017-2414-A, men her fant Høyesterett at skaden var dekket under As avtale slik at A ikke hadde regress mot B:

Et forsikringsselskap A som hadde foretatt utbetaling under en produktansvarsforsikring, fremmet regresskrav mot et annet forsikringsselskap B under henvisning til at forsikringstilfellet oppsto allerede i B's foregående ansvarsperiode. Forsikringstilfellet gjaldt skader på panel og annet treverk som følge av at de spikerne som var benyttet, rustet. Høyesterett kom til at forsikringstilfellet først oppsto når skadene på treverket var konstatert, til tross for at det allerede under B's foregående ansvarsperiode var konstatert at spikerne rustet.

Som nevnt ovenfor gir Høyesterett i denne saken også uttrykk for at såfremt A ville hatt regress mot B, spiller det ingen rolle om sikrede ikke hadde meldt kravet under Bs forsikring. I ansvarsforsikring kan imidlertid en slik løsning forklares med at meldefristen i fal. § 8-5 ikke gjelder i forhold til skadelidte, og at skadelidte har et direkte krav mot selskapet. Skadelidte kunne derfor meldt kravet mot B, og da kan det virke tilfeldig at B skal slippe ansvar fordi kravet ikke er meldt av sikrede.

\section{Regress mot forsikringstaker/sikrede}

\subsection{Noen utgangspunkter}

Dersom forsikringen kun omfatter forsikringstakerens egne økonomiske interesser vil det normalt ikke være tale om regress mot forsikringstaker. Selskapets ansvar vil da bestemmes

78 Brynildsen, Lie \& Nygaard 2014 s. 230-231.

79 Slik også HR-2018-577-A avsnitt 36, og HR-2017-2414-A avsnitt 47. 
gjennom forsikringsavtalen, og hvis forsikringstaker eller sikrede har brutt noen plikter må han evt. finne seg $\mathrm{i}$ avkortning eller avslag på erstatning.

Det blir heller ikke tale om regress dersom det er en annen enn sikrede som har krav på erstatning, såfremt denne andre ikke har større rettigheter under forsikringen enn sikrede har. Dette vil være tilfelle ved uselvstendig medforsikring og vanlig ansvarsforsikring i den utstrekning selskapet har innsigelser som knytter seg til sikredes adferd før forsikringstilfellet inntraff.

Spørsmålet om regress forutsetter derfor at selskapet har betalt ut erstatning til en medforsikret eller skadelidt hvor det overfor sikrede kunne påberope seg avkortning eller ansvarsfrihet. Dette kan skje ved selvstendig medforsikring, og ved ansvarsforsikring hvis selskapet må betale til skadelidte selv om det har innsigelser overfor sikrede. Situasjonen er særlig praktisk ved tvungen ansvarsforsikring hvor selskapet i forhold til skadelidte ikke kan påberope seg de subjektive innsigelser det måtte ha mot forsikringstaker/sikrede. Fal. har ingen regler om regress mot sikrede i slike tilfelle. I tvungen ansvarsforsikring kan regress derimot være hjemlet i de preseptoriske ansvarsforsikringsreglene eller i forsikringsavtalen, se punkt 7.2. Spørsmålet om hva som gjelder uten slike bestemmelser diskuteres i punkt 7.3.

\subsection{Lovhjemlet eller avtalefestet regress mot sikrede}

Eieren av en bil har plikt til å tegne trafikkforsikring for bilen etter bal. § 15. Ifølge bal. § 4 er trafikkforsikringen overfor skadelidte ansvarlig for enhver skade som bilen «gjer». Bal. forutsetter imidlertid at det inngås en forsikringsavtale mellom bileieren og trafikkforsikringselskapet, og rett til regress mot sikrede kan følge både av bal. og av forsikringsavtalen.

Bal. § 12 første ledd a) og b) gir selskapet rett til regress mot sikrede dersom han har voldt skaden ved grov uaktsomhet eller forsett, eller skaden er voldt mens føreren var påvirket. Regresskravet kan lempes etter skl. § 5-2.

Trafikkforsikringsavtalen kan i tillegg ha begrensninger i forsikringens dekningsfelt i forhold til bal. $\S 4 .^{80}$ Tradisjonelt har slike avtaler i så fall forbeholdt seg rett til regress om trafikkforsikringen må betale ut til skadelidte ${ }^{81}$ Et regressansvar etter bal. kan lett fremstå som urimelig for en forsikringstaker som har betalt premie og tror han har beskyttelse mot ansvar. Høyesterett har antatt at henvisningen til lempning i bal. § 12 om regress også gjelder for regresskrav som bygger på trafikkforsikringsavtalen. ${ }^{82}$

$80 \quad$ Selmer 1982 s. 347-348.

$81 \quad$ Selmer 1982 s. 348.

82 Rt-1976-682; Selmer 1982 s. 348. 
Advokater har plikt til å stille sikkerhet etter domstolloven § 222 og advokatforskriften $\S 2-1$ følgende. Sikkerhetsstillelsen etter advokatforskriften gjelder «erstatningsansvar som advokaten pådrar seg ved ut $\varnothing$ velsen av advokatvirksomheten». ${ }^{83}$ Den har ikke unntak for straffbare eller forsettlige handlinger, som ville vært unntatt etter fal. § 4-9. Den har heller ikke regler om frist til å melde fra om forsikringstilfellet, jf. fal. § 8-5, og den gjelder i tre måneder etter at den er oppsagt. I den utstrekning forsikringsavtalen mellom advokaten og sikkerhetsstilleren inneholder plikt- og/eller fristregler som har hjemmel i fal., og sikrede bryter disse, er det spørsmål om selskapet har rett til regress mot advokaten.

Advokatforskriften inneholder ikke selv noen regler om regress. Kravet om sikkerhet gjennomføres imidlertid normalt gjennom en todelt forsikringsavtale hvor man kombinerer den påbudte sikkerhetsstillelsen med en profesjonsansvarsforsikring som følger forsikringsavtalelovens regler. Sikkerhetsstillelsen kan ha en regressklausul som holder advokaten ansvarlig for de beløp som ikke er dekket av profesjonsansvarsforsikringen: ${ }^{84}$

\title{
2.5. Regress
}

Sikkerhetsstiller har rett til å kreve full regress for enhver utbetaling under sikkerhetsstillelsen. Regress gjøres primært mot profesjonsansvarsforsikringen. Dersom kravet helt eller delvis ikke dekkes av forsikringen, kan regress på udekket beløp fremmes mot advokaten.

\subsection{Annet regressgrunnlag?}

Ifølge forsikringsavtalelovens forarbeider vurderte lovutvalget om det var nødvendig å ta inn regler om regress i utkastet, men kom til at dette ikke var tilfelle. ${ }^{85}$ Begrunnelsen var at dette ikke hadde vært særlig praktisk under fal. 1930. Men utvalget presiserer på s. 152 at

\begin{abstract}
«Det må antas å følge av alminnelige rettsregler at den som er skyld i at selskapet pådrar seg et ansvar overfor tredjemann utover det som følger av forsikringsavtalen som sådan, vil kunne pådra seg ansvar overfor selskapet. I forhold til forsikringstager, sikrede eller en medforsikret vil likevel et slikt regresskrav måtte underlegges de samme vernereglene som disse personene beskyttes av når de selv gjør gjeldende krav under forsikringen, se for så vidt Selmer s. 129-130. Bestemmelsene i kapittel 4 står her særlig sentralt».
\end{abstract}

Uttalelsen gjelder «den som er skyld i at selskapet pådrar seg et ansvar overfor tredjemann utover det som følger av forsikringsavtalen som sådan». Den omtaler derfor bare den situasjonen at selskapets ansvar er en følge av sikredes uaktsomme adferd. Dette vil være tilfellet om forsikringstilfellet er en følge av at sikrede bryter sine omsorgsplikter etter fal. kap. 4, og selskapet må betale ut erstatning til en medforsikret eller en skadelidt. I slike

83 Advokatforskriften $§ 2-3$ første ledd.

${ }^{84}$ https://www.advokatforeningen.no/PageFiles/858/Vilk\%c3\%a5r\%20profesjonsansvar\%201 mai_2018.pdf

85 NOU 1987:24 s. 151-152. 
tilfeller har sikrede forutsetningsvis utvist uaktsomhet, og det følger da i utgangspunktet av alminnelig erstatningsrett at selskapet har et krav mot ham. Sikrede nyter imidlertid godt av de samme vernereglene som ville vært gjeldende om det var han som reiste et krav om forsikring. Regresskravet må derfor behandles på samme måte som om sikrede reiste kravet under forsikringen og kravet måtte avkortes etter reglene i fal. kap. 4. Forsikringen gir altså sikrede en indirekte ansvarsforsikring i forhold til andre medforsikrede under avtalen på samme måte som medforsikrede har en indirekte ansvarsforsikring når han volder skade på sikredes eiendeler.

Et eksempel er hvor den forsikrede bygningen brenner ned pga. grov uaktsomhet hos forsikringstaker og selskapet må betale erstatning til panthaver. Hvis bygningens verdi er 100 og pantet utgjør $75 \%$, har forsikringstaker krav på 25 og panthaver på 75 . Hvis man tenker seg $50 \%$ avkortning for grov uaktsomhet får forsikringstaker 12.5. Panthaver er beskyttet mot avkortning og har krav på 75 uavkortet. I så fall vil selskapet kunne kreve regress hos forsikringstaker, men bare for $50 \%$ av beløpet.

En tilsvarende beskyttelse vil sikrede ha i tvungen ansvarsforsikring hvor selskapet ikke kan påberope seg sikredes brudd på opplysnings- og omsorgspliktene mot skadelidte. ${ }^{86}$

I ansvarsforsikring kan selskapet også bli ansvarlig overfor skadelidte hvor sikrede oversitter fristen til å melde forsikringstilfellet slik at sikrede selv har mistet sitt krav mot selskapet. Denne situasjonen er ikke løst i forarbeidenes uttalelser. I utgangspunktet vil sikrede og selskapet her begge være ansvarlig overfor skadelidte. Dette gjelder også ved tvungen ansvarsforsikring etter bal. og advokatforskriften. ${ }^{87}$ Skadelidte kan i så fall velge om han vil holde seg til skadevolder eller til ansvarsforsikringsselskapet, slik at disse har et solidaransvar. Regress fra ansvarsforsikringsselskapet mot ansvarlig skadevolder kan i dette tilfellet ikke følge av legalcesjon fordi sikrede og skadevolder er samme person og det er derfor ikke noe krav å tre inn i. Derimot kan regress følge av en analogi av skl. § 5-3 når flere er solidarisk ansvarlig for samme skade. ${ }^{88}$

Preventive hensyn tilsier at ansvarlig skadevolder dekker tapet, men dette har han betalt en premie for å overføre til selskapet. For selskapet blir det derfor en tilfeldig fordel om det skal kunne tilbakeføre tapet til sikrede fordi meldefristen er oversittet. Dette er imidlertid et generelt argument mot regler om preklusjon og foreldelse. Begrunnelsen for fal. § 8-5 er selskapenes behov for oversikt over forventede krav bl.a. for å varsle reassurandører og sikre bevis. Dette synspunktet ble godtatt som et legitimt hensyn i Rt-2011-646, hvor det var

$86 \quad$ Fal § 7-7 annet ledd. For vanlig ansvarsforsikring er innsigelsene i behold såfremt de dreier seg om sikredes forhold før forsikringstilfellet inntraff.

$87 \quad$ Sikrede hefter etter bal. $§ 11$ etter alminnelige erstatningsrettslige regler. Advokatforskriften $§ 2-2$ sier at sikkerhetsstilleren skal påta seg å innestå for oppfyllelse av advokatens ansvar etter reglene i forskriften.

88 Jf. Rt-2005-870 avsnitt 45: «Når skyldnere er solidarisk ansvarlige, er retten til regress et naturlig - og nødvendig - supplement, som gjør det mulig å plassere byrden der den bør være ut fra forholdet mellom de ansvarlige og omstendighetene for $\varnothing v$ rig, uavhengig av hvem som tilfeldigvis tar ansvaret overfor skadelidte.» 
spørsmål om et revisjonsfirma måtte identifiseres med den ansvarlige revisor mht. hans kunnskap om forhold som begrunnet kravet mot selskapet, og som altså utløste tidsfristen i fal. § 8-5. Høyesterett konkluderte med at identifikasjon måtte finne sted til tross for skadevolderens argument om at dette ville medføre en tilfeldig fordel for selskapet fordi de hadde fått premie for å dekke ansvaret.

Konsekvenshensyn taler derimot for regress. Om skadelidte hadde reist et krav mot sikrede skadevolder, og sikrede skadevolder etter å ha betalt skadelidte reiste kravet mot forsikringen, kunne forsikringsselskapet avslå med hjemmel i vilkårene. Det forhold at skadelidte er gitt en utvidet rettighet mot selskapet er i utgangspunktet skadevolder uvedkommende. Hvis skadevolder skal kunne oppnå en fordel ved at skadelidte holder seg til selskapet fremfor å gå på skadevolderen først, ville dette medføre en helt tilfeldig berikelse for ham. Det er også uheldig om løsningen skal bli forskjellig avhengig av hvem skadelidte velger å forholde seg til i første omgang. De beste grunner taler derfor etter min mening for full regress mot skadevolder, men spørsmålet er åpent.

\section{Oppsummering og noen refleksjoner}

Fremstillingen viser at spørsmålet om regress i skadeforsikring oppstår i en rekke forskjellige sammenhenger med forskjellig partsforhold, forskjellig regressgrunnlag og forskjellig fordeling mellom partene i regressomgangen. Forskjellene forklares med at det er forskjellige hensyn som ligger til grunn for regressreglene.

Ved regress fra forsikring mot ting- og formueskade mot skadevolder og ansvarsforsikringen er det preventive hensyn som er utslagsgivende. Slike hensyn veier dermed tyngre enn kostnadene ved regressoppgjør. Det har derfor interesse å se at man tross preventive hensyn i visse tilfelle kanaliserer ansvaret til skadelidtes forsikring mot tings- og formueskade. Dette gjøres dels som en preseptorisk kanalisering valgt av lovgiver som del av den nordiske lovgivningsmodellen, dels som ledd i en profesjonell knock-for-knock regulering. Selv om utgangspunktet er forskjellig, er det imidlertid et felles karakteristisk trekk at regress koster tid og penger som i neste omgang må finansieres gjennom forsikringspremiene, og ut fra effektivitetshensyn kan det være fornuftig å kanalisere mest mulig til skadelidtes egne forsikringer. I disse tilfellene gis derfor prevensjonshensynet mindre gjennomslag.

Ved flere skadevoldere/ansvarsforsikringer gjelder fordelingsmomentene i skl. § 5-3. Dette gir en fleksibel løsning hvor man både kan ta hensyn til prevensjon og årsaksforløp, og dessuten unngå at skadelidtes valg blir bestemmende for den endelige plasseringen av tapet. Kostnadene ved overflytting av tap gjennom regress oppveies dermed av prevensjons- og rettferdshensyn. 
Ved dobbeltforsikring er formålet å beskytte sikredes valgrett samtidig som man hindrer at sikredes valg bestemmer ansvarsfordelingen mellom selskapene. Men for $\emptyset v r i g$ har selskapet ikke noen beskyttelsesverdig interesse i denne regressadgangen. De har fått premie for full dekning og kan ikke regne med at interessen er forsikret flere steder.

Ved regress mot sikrede dreier det seg normalt om forsømmelser fra sikrede som pga. preseptoriske regler ikke kan påberopes overfor en medforsikret eller skadelidte som har rettigheter etter avtalen. Begrunnelsen her er i første rekke preventive hensyn. Slike hensyn kan imidlertid ikke forklare regress hvis sikrede oversitter meldefristen etter fal. § 8-5 eller hvor forsikringsavtalen har objektive begrensninger utover det som lovverket sier ved tvungen ansvarsforsikring. Ved oversittelse av meldefristen dreier det seg imidlertid om å beskytte selskapets behov for oversikt over sine forpliktelser som er akseptert av lovgiver. Ved objektive ansvarsbegrensninger kan det derimot reises spørsmål ved om dette er en hensiktsmessig risikodeling mellom partene $\mathrm{i}$ avtalen. 